\title{
"AM I A ROGUE PALMERIN OR LANCELOT?": AUTHORIAL IDENTITY IN THE NOVELS ERASURE AND THE WATER CURE BY PERCIVAL EVERETT
}

\begin{abstract}
Summary. The article examines the way authorial identity is explored in two novels by a contemporary American writer Percival Everett Erasure and The Water Cure, using a comparative-contrasting method. The subject matter of identity is one of the most widely discussed in American culture. In many of his works Everett questions how identities are created in society and exposes the obvious inadequacies within the system. Authorial identity has become a major recurring theme of Everett's oeuvre. It allows the author to continuer a never-ending conversation about art and the role of artist in developing a reading audience's aesthetic taste. By incorporating the subject matter of authorial identity the author informs the readers and academic world about his principle critiques of policies ruling the publishing world. Exploring the subject of authorial identity allows the author to raise questions of race as related to freedom and boundaries of authorial self-expression. The novels picture split or dual identities of protagonists, so the research focuses on the constituents shaping these identities of the fictional authors and offers some reflections on social and cultural reasons leading to the current publishing policies in contemporary America. It demonstrates that Everett's novels depict how the identity of black American writers is forcibly shaped by popular culture and consumerist society. By referring to the subject of authorial identity Everett raises his voice against ongoing stereotyping of black authors. The paper offers an alternative way of interpreting titles of both novels. It suggests that erased in Erasure, alongside with the commonly seen racial background of the fictional author, is intellectual authorial self. As well as in The Water Cure, tortured is authorial voice, which has never been given way.
\end{abstract}

Key words: authorial identity, identity components, Percival Everett, Erasure, The Water Cure.

Problem Statement. Literary works of Percival Everett, a highly accomplished and prolific contemporary American writer, are little known in Ukraine due to the absence of Ukrainian translations. He is an author of more than twenty novels, a number of poems collections, three collections of short stories, and a children's book. His fiction, picking up L. Krauth's view is "not only engaging but also provocative - altogether, an accomplished body of important work" [1, p. 313]. Scholars admire the diversity of genres presented in a remarkable style whose hallmarks are rich language, well-crafted dialogue, playfulness, and humor - both funny and wry, as well as daunting erudition, which place the author beyond mainstream literary recognition.

The subject matter of identity is one of the most widely discussed in American culture, therefore in many of his works Everett questions how identities are created in society and exposes the obvious inadequacies within the system. M. Russet points out that "the integrity of Everett's project consists in maintaining an unrelenting assault on constructing fictions of identity - be they racial, generic, authorial or even corporeal..." [2, p. 366]. Authorial identity as a matter of specific attention is incorporated in the thematic world of two novels "Erasure" (2001) and "The Water Cure" (2007). Both novels have gained enthusiastic acclaim of critics as authentic post-modernist texts packed with numerous metanarrative devises and fragmentally structured. Everett creates the characters with split or dual identities and describes a dramatic identity crisis resulting from it.

Objective statement. This paper aims at showing how and why the subject matter of authorial identity becomes a recurring theme in Percival Everett's works, how it is explored in his novels Erasure and The Water Cure, and what cultural and societal problems it exposes. The objectives of the study involve comparing and contrasting the ways of unfolding the subject of authorial identity; the techniques of constructing authorial identity; a type of protagonist used to reveal the subject matter; and offering alternative interpretation of both novels' titles.

Analysis of recent research and publications. Everett's works attract attention of American and French scholars. American scholars (J. Dittman, S. Griffin, A. Stewart, R. Schur, [3], U. Cannon [4], M. Russett [2]) mostly discuss racial and identity problems brought up in his works, some analyze theoretical aspects of the text structure (R.J. Roof [5], R. Dorris [6], S. Morton [7]), French scholars (S. Bauer [8], M. Feith [9], C.A.-L. Tissut [10]) scrutinize Everett's texts through the lens of popular structuralistic theories struggling to unfold the meaning. Although the topic of identity, quite predictably, could not escape the researchers' attention (A. Stewart [11], J. Dittman [12]), Everett's perspective on the subject matter of authorial identity in his novels Erasure and "The Water Cure" has never been specifically studied before in comparative mode.

Main body. Throughout his novels Erasure and The Water Cure, Everett puts his own view of authorial identity in a larger context. It is worth mentioning that Percival Everett presents a phenomenon in contemporary American literature. Publishers and scholars tend to keep him within the race framework of an "African-American author." This categorization imposes certain expectations on the author to inherit and continue bearing the burden of all the racial, historical, and cultural baggage involved. However, Percival Everett refuses to be categorized at all. He chooses to release himself from the burden of universal representation of the black 
experience and enjoy artistic freedom of expression. J. Dittman argues that Everett constructs his own authorial and racial identity, refusing to be racially identified as an "African-American" writer, he prefers to exist as a "writer", "an artist", who just makes art, who happens to be black and not an African American writer" [12, p. 3]. For Everett, it is of great importance to maintain "a coherent identity as an artist and an author" [2, p. 364]. Keith B. Mitchell and Robin $\mathrm{G}$. Vander in the Introduction to the collection of essays on P. Everett (2013) admit that "Everett's unique authorial voice is majorly departing from other African American writers of his generation and of the past" [3, p. XII]. In constant confrontation with the publishers "Everett has made his career of writing against proscriptions of black representations in his fiction" [3, p XIII].

Unlike other African American authors, for example, Ralph Ellison, Tony Morrison, Alice Walker, Charles Johnson, Clarence Major, John E. Wideman, and Colson Whitehead whose works are clearly rooted in identifiable black experience and black expression, Everett's fiction is far more cosmopolitan. In his works, he often refers to numerous representatives of the world's culture - philosophers, artists, writers, and public figures, thus signifying that his fiction stems from Euro-American cultural tradition and clearly marking out his aesthetic territory in American and world literature. His works raise complicated and universal questions of what it means to be human regardless of racial, social, or cultural background. This explains the growing interest in his fiction among European readers and scholars who are ready to view Everett as an artist irrespective his racial background [3].

The subject of identity in general, and authorial identity in particular is one of the most recurrent in his works, and we are going to show why.

In Erasure, the subject matter of black author's authorial identity, as well as racial identity, is introduced at once, at the very first page by short and precise statements: "I am a writer of fiction $<\ldots>$ I am black; that is my race" [13, p. 1]. In The Water Cure, the subject of authorial identity is introduced indirectly. Everett encourages the reader to actively participate in identity quest, because he believes it is for the reader to use cognitive abilities and deduce "from some hint or insinuation of evidence left tethered to the fraying ends of lines" [14, p. 139]. The occupation of the protagonist is mentioned on page 25 , in a self-introductory paragraph "I am able to write novels (romance though they be) for a living" and further "I am Ishmael Kidder, but I am better known as Estelle Gilliam, the romance novelist" [14, p. 25]. The hint about race is dropped only on page 35 . The protagonist is addressed "my dark friend" $[14$, p. 35] by the ghost of Thomas Jefferson in an imaginary conversation. This way, the reader finds out that the protagonist is a black writer who publishes romantic novels disguised as a white female writer, which gives him a lot of pain and eventually causes a hard-to-accept identity crisis.

The identity of both protagonists is complex. We are going to find out what components the author utilizes to illustrate the complexity of these identities. Apparently, both characters perform a set of different social functions which shape their identities.

The protagonist in Erasure, Thelonious Ellison, also known as Monk, a black writer of intellectual fiction, is a university professor, and also a loving son and a brother. The primary part of this complex identity is that of an author, who constantly emphasizes his devotion to the aesthetics of high art. His literary taste and authorial style had been shaped by the outstanding works of the world literature. As an author of fiction that is too difficult for the average audience to understand, he faces numerous rejections by publishers who think that he "is not black enough," meaning he doesn't produce "the true gritty real stories of black life" [13, p. 2], which are more marketable than experimental novels. Having been rejected seventeen times by publishers, Monk, in a fit of anger and being hard-pressed with family financial problems, produces a parody - a true ghetto-style piece of fiction disguising himself as a "real black author" nicknamed Stag Leigh. Surprisingly, the "so called novel" quickly gains critical acclaim and enjoys an incredible commercial success. No matter how hard the protagonist tries to resist his alter-ego overtaking his identity, the consequences of this conversion become irreparable. Eventually, the invented identity of a "tough black novelist" completely conquers the writer of intellectual fiction, leaving the reader with the belief that money will always overpower any aspiration for the real art.

The identity of Ishmael Kidder from The Water Cure is also initially made of several components, including his being a black man, a divorced father, and a writer of fiction. The first two are associated with masculine nature and call for action, casting light on Kidder's involvement in his daughter's case by trying to find her abductor and achieve justice in his own way. The third constituent is problematic, as it is of double nature. Kidder writes and publishes under the name of Estelle Gillam, a white female writer, and works in the genre of romance novels. His real authorial self seems not to have any way out, as he wants to produce highbrow intellectual fiction. This side of his identity is represented in the novel through highly sophisticated narratorial breaks characterizing a writer of fiction who is eager to develop a career of a serious artist. It is brought through self-reflexive interior speeches, abundant philosophical reflections on essence of life, art and human relations, extensive meditations, testifying to brilliant educational background, thorough knowledge in philosophy, well developed analytical mind, which altogether shape a mindset of a highly intellectual writer. Hence is the question, the protagonist asks himself: "Am I a Palmerin or Lancelot?" [14, p. 148] featuring completely opposite value characters in literature.

However, in The Water Cure, initially, Ishmael Kidder seems not to have any remorse taking up a fake authorial identity. The decision had been made long before, and he appears to have accepted it as a minor evil, using it as a simple instrument of providing oneself a good living. Presently, Ishmael enjoys the tangible outcomes: "I am able to write novels (romance though they be) for living. $<\ldots>$ Luckily, I am wealthy" [14, p. 25]. Wealth makes him put up with inconveniencies of being disguised under the invented identity of a white female novelist. Anyway, behind this seemingly complete acceptance, there appears to be a deep confusion in the protagonist's mind about his identity: "who I am and am not" [14, p. 25]; "how is it that I am I, or me, the $I$ or me depending on whether the first $I$ is really $I$ and nor merely some word ' $I$ ' designating another ' $n o t$ I"' [14, p. 51]. This kind of reflection brings Ishmael to conclusion that "the only real identity I have is my spatial orientation to the rest of the world" [14, p. 51].

Erasure's protagonist Monk, quite the opposite, is far from accepting his fake alter-ego. As crafting ghetto pieces of fiction has not gone into mass production yet, his creative personality suffers a great deal. The fear of being discovered drives him almost crazy 
and the shame brings him a real physical pain: "there was nothing in the writing that self-consciously threw it back on me... $<\ldots>$ I was thinking myself onto a funk about idiotic and pretentious bullshit to avoid the real accusation staring me in the face. I was a sell-out" $[13$, p. 160].

Everett depicts the writers, who are wrestling heavily with their unfortunate duality: "I consider a person other than myself who is exactly like myself to a point that any given characteristic I might attribute to myself can also be attributed to that other, so identical, that any other trait I attribute to myself must be attributed to that other. Are we identical?" [14, p. 59]. Confused identity of the protagonist in Erasure is revealed in a humorous key. As having to play in public the role of his alter ego really complicates Monk's life, he seems to be losing a sense of reality: "Thelonious and Monk and Stag Leigh made the trip to New York together, on the same flight, and, sadly, on the same seat" [13, p. 238]. The protagonist admits to the situation of "actual condition of dual personalities" [13, p. 238], We would say even tripled personality. A similar episode of concurrent double identity can be found in The Water Cure: "Ishmael Kidder aka Estelle Gilliam shook his head" [14, p. 154]. However, identity crisis feels far deeper in The Water Cure, as a fictional writer had been practicing his fake identity for quite a time and has almost spliced with it. Why did the protagonist begin to suffer from identity loss after the death of his daughter? He gives the answer himself. Different identity was a sort of shield for him, a refuge from himself, a fence to hide behind from his traumatised mind "Perhaps as a defense, I never felt a need to fully comprehend the language of my art, or rather what my so called art might actually be" [14, p. 65].

Both novels use the first-person narration which gives the reader a better insight into the mindset of both protagonists. Erasure's first person is predetermined by the form of a personal journal, whose entries bring the protagonist's personal and professional situation clear to the reader. It is written in a distinct confessional mode. The Water Cure's first person is also delivered as a confessional, highly fragmented narration, which can hardly be identified as narration at all. S. Morton called it "narrative post-apocalypse" [7, p. 196]. We would suggest that it bears every sign of an abstract patterned narration, Everett is so deliberately aiming to construct [15, p. 224]. From the opening monologue, it forces the reader to believe that the narrator is repenting some deadly guilt $[14, p .7]$. The type of guilt remains unclear throughout the novel as the author provides the reader with the answer, not the question: "the true answer to your question is shorter than the lie. Did you? - I did" [14, p.7], which sounds most misleading. After reading the novel the reader feels inclined to fill up the gap and find out whether the protagonist really abducted a man and tortured him in his own basement (the main event in the plotline). Possible implied question for the reader to challenge the protagonist might be "Did you break your artistic code and author that bunch of low-brow romance fiction under a white woman's name?" Apparently, the answer to this unarticulated question would also be "I did".

As it becomes clear, both protagonists are the writers of fiction: Monk - numerously rejected author of intellectual fiction, and Ishmael Kidder - a potential writer of high-brow texts, who recycles fragments of his non-existing, unwritten intellectually challenging pieces in his head. Both protagonists are forced to withdraw from the highbrow literature writing for the sake of satisfying their immediate needs and making a living. All this considered, the titles of both novels allow alternative interpretations.

The scholars keep wondering "What is being erased and by whom?" in Erasure, presuming that the fictional narrator was trying to erase racial past and racial present [16, p.145; 2, p. 359-360]. Alongside with these, we would argue, erased appears to be the authorial identity of an intellectual black author. In order to meet the editor's expectations of reflecting a "true black experience," Monk constructs his own fictitious substitute and erases his intellectual identity tuning his mind up for a commercial piece of fiction.

As for The Water Cure, it remains unclear who or what is "cured with water" in the protagonist's basement, whether there is a real victim of abuse - the rapist and the murderer of the protagonist's daughter - or the fragments of the novel telling about this action are mere products of the protagonist's authorial imagination or even simply notes for his own piece of fiction, swarming in his mind, different from Estelle Gilliam's feminine writing style which he has so long been exercising. In The Water Cure, the author provides no clues as to the relationship between the passages and the narrative strand. Passages of the Everett's novel may well be confused with the passages from Ishmael Kidder's imaginary texts. They look like random passages until the narrator mentions the titles of the novels he actually writes under the pseudonym Estelle ("The Wind's Kiss, The Kiss of Midnight, Midnight Light, The Light of my Recovery, The Recovery of Passion, Passion's Return to Gentle, The Gentle Storm" [14, p. 70]) and the titles of pieces he would rather write instead ("The Pressure of Observation, Deeper, Analytic of the Sublime, The Fundamental Concepts, The Principia, Other Languages Are All we have" [14, p. 70]. The reader finds hard pressed to attribute the fragments to either Everett's own narrative or the fictional writer's notes for unwritten novels. Everett never helps his reader out, he encourages the reader to decide if there are links and where to locate them. Everett offers his reader a tour of his narrator's mind, which is metaphorically presented as "the least clean room, in that world that remained mine" $[14, \mathrm{p}$. 70]. Bouncing between fragments, the reader encounters bits and pieces of unexpressed thoughts inhabiting this mind. These thoughts constitute content of the imaginary works, Kidder would like to write one day but never got to them. Trends of these thoughts testify to him possessing deep philosophical mindset which would signify his strong masculine identity.

We cannot but side with A.-L. Tissut who seems to be sure that "a number of hints make it unclear whether the narrator did capture and torture the alleged murderer. On many occasions doubt is shed as to the actuality of events, according to a twofold move of alternate overexposure and ellipsis, leaving us with our projections, resort as we may, to intellectual fallacy in order to analyze the narrator's aims, and the author's behind him" [10, p. 8]. Following the same key, J. Roof [5, p. 213] sets a question who is "his tortured scapegoat - the suspect or the reader or the hypernarrator himself," stating that it is difficult to discern [5, p. 213]. The torture with the water known as the water cure, in such case, can be viewed as a kind of torture exercised on fictional writer's own authorial self. Evidence of this figurative torture applied not on his physical body, but on his artistic self can be found in the novel. Apparently, Kidder tortures that component of his own authorial identity which has not yet been given any real voice ("in the absence of that voice, my voice” [14, p 65]) and is duct-taped in the basement of his mind. 
The clue to such reading is placed in the paragraph on page 65 , "Since the time of my child's death I had been unable to make any mark on any surface that might be my own, but somehow Estelle Gilliam found a voice and life," although he refused to consider his invented identity for his own alter ego.

M. Russett suggests that Erasure has strong biographical referent and points out a number of common features between the author of Erasure and his character, including race, family background, education, erudition rate, musical interests, and hobby inclines [2, p. 359]. So, it is well justifiable, that Everett makes his protagonist Thelonius Ellison a mouthpiece for his critique of the publishing world and its marketing policies as well as academe, who apply vague criteria of "authenticity" while defining the merits of literary works, thus failing to shape a good taste in literary audience. As for The Water Cure, P. Everett declared his own opinion in the foreword to the novel, which says: "African-American writers were, and in some ways still are, stuck trying to supply fictions that are palatable to American culture's tastes and expectations and do not upset how America wants to see black people and itself' [3, p.10]. This testifies to the fact that the situation described in the novels is not invented, nor is it a single episode. Self-conscious self-fabrication has become an irreversible condition in the world of fiction writing. Here comes the question of readerly assumptions and readerly expectations and whether African-American writers should succumb to them or resist them. P. Everett made his point clear at an early stage of his career in the essay published in 1999: "I do not believe that the works we produce need to be any different: the failing is not in what we show but in how it is seen. And it is not just white readers, but African-American readers as well who seek to fit our stories to an existent mode. It is not seeing with 'white' eyes, it is seeing with 'American' eyes, with brainwashed, automatic, comfortable, and 'safe' perceptions of reality" [17, p. 175-176]. Everett, apparently, is not going to let down his artistic principles to flatter the readers' expectations, quite on the contrary, all of his oeuvre is tuned to build up aesthetic taste and intellectual power of his own reader.

Conclusion. By fictional erasure and the water cure of the intellectual authorial identity of his characters Everett raises his voice in protest against pigeonholing and stereotyping of black authors at large. He believes that policies of publishing houses are unfair and agents representing them are still being very prejudiced towards contemporary African-American writers. He aims to reshape the aesthetic expectations of the reading public to give African-American writers their real voice.

The novels by Percival Everett offer a realm of ideas for research in the field of experimental novel, genre, narration, language, and other literary categories, applying any postmodernist critical approach. Utilizing Antony Stewart's impression: "Everett's novels occupy and draw our attention to the spaces in between conventional notions of literary fiction and equally conventional motions of literary theory" [11, p. 216]. Surprisingly, every new research on Everett's works does not provide answers to the questions, but provokes more interesting questions for further discussions.

\section{References:}

1. Krauth Leland. Undoing and Redoing the Western. Callaloo. Vol. 28. November 2, Spring, 2005. P. 313-327.

2. Russett Margaret. Race under Erasure. Callaloo. Vol. 28. November 2, Spring, 2005. P. 358-368.
3. Perspectives on Percival Everett /ed. Keith B. Mitchell and Robin G. Vander. University Press of Mississippi, 2013. 167 p.

4. Cannon Uzzie Teresa. Against the Grain: Black Masculine Narrative Insurgency in Contemporary Fiction. Greensboro USA today. 2004. 178 p.

5. Roof Judith. Everett's Hypernarrator. Canadian Review of American Studies. Vol.43, November 2, Summer 2013, P. 202-215.

6. Dorris Ronald. Framing Text to Set Discourse in a Cultural Continuum // Perspectives on Percival Everett /ed. Keith B. Mitchell and Robin G. Vander. University Press of Mississippi, 2013. P. 35-59.

7. Morton Seth. Locating the Experimental Novel in Erasure and The Water Cure. Canadian Review of American Studies. Vol. 37. November 3, 2007. P. 189-201.

8. Bauer Sylvie. "Nouns, Names, Verbs" in The Water Cure by Percival Everett, or "Can a Scream be Articulate". Revue francaise d'etudes americaines. 2011/2. № 128. P. 99-108.

9. Feith Michel. The Art of Torture in The Water Cure by Percival Everett// Revue francaise d'etudes americaines. 2012/2. № 132. P. 90-104.

10. Tissut A. L.Percival Everett's The Water Cure: A Blind Read. Sillages critiques. Iss. 17, 2014. P. 1-10. URL: https://journals.openedition.org/ sillagescritiques/3496.

11. Stewart Anthony. Uncategorizable Is Still a Category: An Interview with Percival Everett. Canadian Review of American Studies. Vol. 37. November 3, 2007. P. 216-224.

12. Dittman Jonathan. (re)Thinking Identity and meaning in Percival Ecerett's The Waster Cure. Perspectives on Percival Everett/ed. Keith B. Mitchell and Robin G. Vander. University Press of Mississippi, 2013. P. 3-18.

13. Everett Percival. Erasure. Minneapolis : Graywolf Pres, 2001. 265 p.

14. Everett Percival. The Water Cure. Saint Paul, Min. : Graywolf Press, 2007. $216 \mathrm{p}$.

15. Шкуропат М.Ю. Інтермедіальність як прояв авторської ідентичності. Східнослов'янська філологія: Від Нестора до сьогодення : матеріали VI Міжнародної наукової конференції (Бахмут, 10 квітня 2018 р.). Бахмут : Вид-во Б.І. Маторіна, 2018. С. 223-227.

16. Sánchez-Arce, Ana María. "Authenticism", or the Authority of Authenticity. Mosaic: a Journal for the Interdisciplinary Study of Literature. Vol. 40, Iss. 3. Winnipeg: Sep. 2007. P. 139-156.

17. Stewart Anthony. Introduction: An Assembled Coterie. Canadian Review of American Studies. Vol. 37. November 3, 2007. P. 175-179.

Шкуропат М. «Я негідник Палмерін чи Ланселот?»: авторська ідентичність у романах «Erasure» та «The Water Cure» Персіваля Еверетта

Анотація. У статті досліджується, як саме проблема авторської ідентичності розкривається у двох романах сучасного американського автора Персіваля Еверетта Erasure («Стирання») та The Water Cure («Лікування водою») за допомогою контрастно-порівняльного методу. Тема ідентичності є однією з найбільш широко обговорюваних в американській культурі. У багатьох своїх творах Еверетт задається питанням, як ідентичності створюються у суспільстві, і викриває очевидні недоліки всередині системи. Авторська ідентичність виявилася однією із часто повторюваних тем творчості Еверетта. Це дозволяє автору продовжувати нескінченну розмову про мистецтво та роль художника у формуванні естетичного смаку читацької аудиторії. Включаючи тему авторської ідентичності, автор інформує читачів і науковий світ про своє несприйняття політики видавництв стосовно авторів афроамериканського походження, що панує у світі споживчих цінностей. Дослідження теми авторської ідентичності дозволяє автору порушити расові питання, пов'язані зі свободою та межами 
авторського самовираження. Романи зображують роздвоєну або подвійну ідентичність головних героїв, тому дослідження зосереджує увагу на складниках, які формують ці ідентичності літературних героїв-письменників, і пропонує деякі роздуми про соціальні та культурні причини, що призводять до такої ситуації у сучасній Америці. Показано, що романи Еверетта зображують, наскільки ідентичність чорношкірих американських письменників формується масовою культурою та суспільством споживання. Звертаючись до теми авторської ідентичності, Еверетт підвищує свій голос проти постійних стереотипів щодо чорних авторів. Стаття пропонує альтернативний спосіб інтерпретації назв обох романів. Робиться припущення, що в «Erasure» стирається не тільки расове походження протагоніста, що $є$ загальновизнаним, але й інтелектуальне авторське Я. Так само, як і у «The Water Cure», тортурам піддається змучений авторський голос, якому ніколи не давали волі.

Ключові слова: авторська ідентичність, складові ідентичності, Персіваль Еверетт, Erasure, The Water Cure. 